\title{
London of the Mind-The Narrative of Psychogeographic Antiquarianism in Selected London Novels of Peter Ackroyd
}

\author{
Petr Chalupský \\ ${ }^{1}$ Department of English Language and Literature, Faculty of Education, Charles University, Prague, Czech \\ Republic \\ Correspondence: Petr Chalupský, Department of English Language and Literature, Faculty of Education, Charles \\ University, Celetná 13, Prague 1, 116 39, Czech Republic. E-mail: petr.chalupsky@pedf.cuni.cz
}

Received: October 22, 2013 Accepted: November 13, 2013 Online Published: February 20, 2014

doi:10.5539/ells.v4n1p10 URL: http://dx.doi.org/10.5539/ells.v4n1p10

\begin{abstract}
Peter Ackroyd is traditionally listed among the foremost contemporary representatives of British psychogeographic writing, along with Iain Sinclair, J. G. Ballard, Stewart Home and Will Self. However, his approach differs from those of his more outspoken fellow-psychogeographers both in scope and form, not so much in his non-fiction London: The Biography (2000), but then all the more noticeably in his novels. Using four of his London novels, Hawksmoor (1985), Dan Leno and the Limehouse Golem (1994), The Lambs of London (2004) and The Casebook of Victor Frankenstein (2008), this paper argues that Ackroyd's treatment of the relationship between his protagonists' psyches and the urban territory they inhabit or move along can be more appropriately labelled as psychogeographic antiquarianism, as it is based on storing up and reenacting the city's accumulated experience and probing the various impacts on the minds of its dwellers.
\end{abstract}

Keywords: London, the city of the mind, psychogeography, antiquarianism, walking

\section{Introduction}

What is the relationship between the territory an individual inhabits, occupies or temporarily finds oneself in and this individual's mind? How does the sense of place and space affect one's mood, feelings, emotions and behaviour? What is the actual correlation between the physical topography of a place and the "mental map" one conceives in one's mind while experiencing that place? These are only a few of the many questions psychogeography attempts to respond to, and, at the same time, some of the issues Peter Ackroyd's London novels attempt to render. It is apparent that such a search makes one leave the secure firm ground of exact science and transparent factual accounts in favour of much less tangible, and all the more nebulous and ephemeral, explorations of the effects of the mental and behavioural impacts of mostly urban environments which often defy any rational or logical explication. The irrational, paranormal, or even occult make up a crucial dimension of his concept of London, as he is convinced that there are certain aspects of and events happening in the city which may be regarded as uncanny, and which, in effect, make the city more intricate and eerie and, along with that, even less graspable and knowable. It is precisely this ultimate complexity and incomprehensibility of London, intensified by the pervasive transhistorical, and often supernatural, parallelism, recurrence and echolalia, that is distinctly reflected in his characters' psyches, in their states of mind, and in their trying to discover a firm identity in the fluid and overpowering mass of urban life, regardless of whether they are sensitive enough to actively seek to disclose or establish a close link between their mind and the city, or whether they are merely passive sufferers who find themselves emerged in and carried away by its many and mighty currents. This paper aims to discuss Ackroyd's contribution to contemporary London psychogeography by exploring the various impacts the present and past London has on the psyches of several of his novels' protagonists, namely Hawksmoor (1985), Dan Leno and the Limehouse Golem (1994), The Lambs of London (2004) and The Casebook of Victor Frankenstein (2008).

\section{Psychogeography}

To provide a clear-cut, encompassing and comprehensive definition of psychogeography turns out an extremely difficult, if not impossible, task to accomplish. Guy Debord, one of its founding fathers and most outspoken proponents, describes it as the "study of the specific effects of the geographical environment, consciously organised or not, on the emotions and behaviour of individuals" (1981, p. 8), yet this deliberately broad and vague definition poses further questions, particularly those concerning the very nature of this enterprise - is it an artistic 
movement, a narrative strategy, a set of loosely related ideas, a conscious or unconscious spatial practice, an avant-garde movement, or a subversive political act? As Merlin Coverley suggests, the answer is all these (and perhaps some more), since psychogeography keeps "resisting definition through a shifting series of interwoven themes and constantly being reshaped by its practitioners", as a result of which the "term has become so widely appropriated and has been used in support of such a bewildering array of ideas that it has lost much of its original significance" (2006, p. 10). It follows that psychogeography, most of all, represents a challenging tool for a new, and potentially more radical, reflection, transformation and redefinition of modern urban experience, be it for aesthetic, psychological, ideological or political purposes on the public level, as well as one for providing a "virtual map to the topography of one's consciousness" (Hayes, 2007, p. 8) on the personal level.

No matter how ambiguous and hard to define, psychogeography does possess several predominant characteristic features, out of which four seem to be of ultimate significance: urban walking, the spirit of political subversion, the focus on the mysterious and occult, and the preoccupation with rediscovering the past as a means of casting light on the present. As it derives from the imminent-physical, psychical or even intimate - experience with the urban terrain, the act of unrestricted walking, wandering or strolling around the city proves vital for all the psychogeographic practices, all the more because it gives one certain freedom of motion and spirit as it allows one to stray from the officially prescribed routes and explore the "[1]andscapes of the id" (Sinclair, 2003, p. 306) - the more forgotten, disreputable or otherwise marginal areas overlooked as mundane or banal not only by visitors and tourists, but also by the city's inhabitants. It is a moving or travelling in which the physical dimension is intrinsically interwoven with the mental, one in which thorough planning of the journey gives way to haphazard randomness, spontaneity, intuitiveness and immediateness. Such perception of the urban life naturally arouses interest in its dark and obscure aspects, such as criminality, violence, mysticism and occultism, and finds its vent in gothic and arcane representations of the city space. Psychogeography also fuses the present and the past, as recording the first necessitates excavating the latter. Seeing the city as a "place of dark imaginings [...] is allied to an antiquarianism that views the present through the prism of the past and which lends itself to psychogeographical research that increasingly contrasts a horizontal movement across the topography of the city with a vertical descent through its past" (Coverley, 2006, p. 14). As psychogeography is primarily concerned with the lost or vanishing aspects of the urban space and experience, and, indeed, the suburban as well, it scrutinises both the intrinsic and extrinsic factors behind these processes, which means the forces of the genius loci that have been at work in determining the events which have happened in the area and lives of those who have inhabited it, as well as the external, material and political influences that have caused the transformation or disappearance of the original state.

Psychogeographic walking can be understood as an act of defiance against the present and the future, against the (post-)modern condition that allows, or even causes, the traces of the old city to be wiped out, obliterated, and sunk into oblivion. From the pragmatic perspective, such an act is from inevitably an ineffective and nostalgic one, as it cannot save, and it does not even attempt to do so, the vanishing aspects and properties of these areas. Such walking goes against the current of time, and against the grain of the conventionally habitual notion of urban progress and development, as it "blows back the years, especially in urban contexts. The solitary walker is, himself, an insurgent against the contemporary world, an ambulatory time traveller" (Self, 2007, p. 15). The avid practitioners of psychogeography are a set of reclusive, distinctive, and in the eyes of many eccentric, individuals rather than a social group of common interest and agenda, whose geographically sensitive psyche plastically transforms in response to the territorial impulses. They are concerned with the city's marginal, unofficial, and hidden-from-public-view places and routes, exploring their dark and obscure sides, and seeing the act of walking these areas and rediscovering their lost or forgotten properties as a reactionary act undermining the city's power-holding authorities by deliberately avoiding all the officially approved, proclaimed and promoted routes and territories. The true spirit of the city is thus to be revealed in its shabby backstreets, courtyards, waste-grounds, enclosures and other urban "no man's lands", rather than in the polished, convenient and visitor-friendly downtown sites.

The most prominent representatives of contemporary psychogeographic London writing are Iain Sinclair, J.G. Ballard, Stewart Home, Will Self and Peter Ackroyd. It is especially the first mentioned who is responsible for the current revival and popularity of psychogeography as a literary form. He reestablishes and adapts the figure of the flâneur for the rigours and challenges of his London expeditions, claiming that the concept of aimless urban strolling has been superseded by "the age of the stalker [...], a stroller who sweats, a stroller who knows where he is going, but not why or how" (Sinclair, 2003, p. 75). For Sinclair, walking the streets becomes continuous research into the hidden layers of modern urban experience carried out through the ultimate immersion into the gravity field of its lines of force, resulting in a peculiar combination of spiritual visionariness, political discontent and artistic 
creation: "Walks for their own sake, furiously enacted but lacking agenda [...] Walks as portraits. Walks as prophecy. Walks as rage. Walks as seduction [...] Savagely mute walks that provoke language" (Atkins \& Sinclair, 1999, p. 15). Naturally, the output of such undertakings is inevitably fragmentary and inconsistent, transforming the city into a puzzle whose bits often do not fit together. Dealing with themes such as "fragmentation, multiplicity, hybridity and reinvention" (Bentley, 2005, p. 14), it is a project destined to remain inconclusive, based on the principle of layering and revising rather than complementation, on the practitioner's subjectivity rather than on his or her unbiased observation and recording. Oscillating between topography, antiquarianism and documentarism on the one hand, and psychology and psychoanalysis on the other, psychogeography as a narrative strategy effectively combines historio-geographic scrutiny with psychological self-scrutiny, revelation of the city's unconsciousness together with that of the practitioner, phenomenalistic recording with aesthetic creation.

\section{Ackroyd's Psychogeographic Antiquarianism}

There are, among others, two major features of Sinclair's conception of London and its representation in his writing that ally him with Peter Ackroyd: "an obsessive focus on the repressed history of the contemporary landscape, $[\ldots]$ a coherent project that is both gripping in, and gripped by, its fascination with particular territories, driven by its concern with the rival claims staked by those who would both make and tell the history of those territories" (Mengham, 2003, p. 56), and the vision of the city as a "text that is endlessly recomposed" (Mengham, 2003, p. 63), rewritten, inscribed on, and thus one over which an individual artist has only a limited, if any at all, control. Like Sinclair, Ackroyd is also convinced of the transhistorical power of genius loci, of the underlying forces operating within certain places and areas in London due to which these have managed to retain their particular spirit and atmosphere across centuries till the present day - the old site of the Marshalsea Prison in Southwark, Lambeth and Limehouse, the most poverty stricken parts of the East End, Nicolas Hawksmoor's churches, the British Museum or Clerkenwell. Apart from this, Ackroyd believes that the spirit of the city, its vigour, imagination and perceptiveness, has found its psychical resonance and creative materialisation in the work of a few extraordinary, brilliant individuals, artists, scholars and scientists, whom he labels as "Cockney Visionaries". Thanks to their visionary, intellectual as well as spiritual, capacity, these people, either Londoners by birth or those who happened to live in the city and who became fascinated and inspired by it in the course of their lives, were able to concretise this spirit of the eternal city in their works, which made them stand not only far ahead of their time, but also above chronological time in general, and so they came "to symbolize all the life and energy and variety of the city itself" (London Luminaries and Cockney Visionaries, p. 341). Also, like Sinclair, Ackroyd tries to demonstrate that the accumulation of human experience in these areas is reflected in the body of texts which, creatively or not, record such experience. Therefore, he assumes, in and in between the individual layers of this palimpsestic city, its essence might, if only partially, be revealed, mostly in the form of texts, ranging from poetry, fiction and drama to non-fiction, and including various popular narratives such as folk tales, myths and urban legends.

However, despite his concern for the obscure and occult and his insistence on the inherent interconnectedness between London and its inhabitants' collective as well as individual psyche(s), Ackroyd is by no means a prototypical representative of contemporary psychogeographic tradition personified namely by Sinclair, but also by Ballard and Self. Although he is, or, more precisely, was, the same as many of his novels' protagonists, a keen London walker, his writing, including his non-fiction, lacks the overtly documentary form and narrative perspective, employing instead a combination of prophetic and visionary projections of a timeless and everlasting city in which certain recurrent events and mechanisms occur and operate in a space-time generated by cyclical and spiral temporal patterns. In this respect, his psycho-spatial concept of London is closer to that which Penelope Lively outlines in her novel City of the Mind (1991): "For this is the city, in which everything is simultaneous. There is no yesterday, no tomorrow, merely weather, and decay, and construction. [...] The city digests itself, and regurgitates. It melts away, and rears up once more in another form" (Lively, 1992, p. 24). Moreover, Ackroyd's, and his characters', perambulations are far from politically motivated and subversive as he is primarily interested in the intricate, subtle and often contradictory relationship between personal and official histories within the city as an aggregate of commonly shared experience. Therefore, regardless of Ackroyd's occasional tendency to espouse and promote certain unorthodox, irrational or even radical tendencies and phenomena, his concept of London is generally traditionalist: "Ackroyd's position is one of inherent conservatism in which all change is subsumed within this unending historical overview", and in whose psychogeographic approach "political commitment is sacrificed to historical tradition" (Coverley, 2006, p. 27). His is a fundamentally idealistic vision of the city, one which is based on reconciliation rather than discord, integration, rather than incongruity.

Paradoxically, although Ackroyd would definitely not label his writing as psychogeographic, "the publication of his mammoth London: The Biography in 2000 has been hailed as the moment when psychogeography entered the 
mainstream" (Coverley, 2006, pp. 123-124). In a truly psychogeographic manner Ackroyd invites his readers to accompany him on his roaming around London and across its history, yet in one breath he points out to the ultimate inscrutability of the city which inevitably renders the walker an inactive, astounded observer and receiver of countless stimuli, one who can only approach its immensity and obscurity through a series of epiphanies which may allow him or her, though mostly temporarily, to glance at the city in its complexity and diversity. Ackroyd's image of London and its history corresponds with the ambivalent view of the metropolis shared by its many current inhabitants - it seems fragmentary, discontinuous, unpredictable, often chaotic and therefore difficult to grasp or control. Yet, at the same time, one finds it beautiful in its vicissitudes, seductive in its mysteriousness, and exciting in its potential to surprise, astonish and enrich. Employing the methods of historiography, biography, topography, together with surmising and poetic license, the book is a homage or paean to a London which once existed or which even may have never come into being at all, an attempt at composing the city's many-sided yet ultimately fascinating literary image, a self-contained and self-sustained textual construct whose author's research and method include the investigation of impacts of the urban milieu on its dwellers' mental processes.

Ackroyd's approach to London sees the aspects of its "unofficial" history as being as, or even more, important than the "official" ones. Therefore, in accordance with the contemporary narrative concern "with the abstract quality of provincial urban dynamics" (Tew, 2004, p. 89), London: The Biography always tries to discover and look into the hidden, dubious, ludicrous, enigmatic or otherwise irrational forces, elements and mechanisms and, consequently, find their impact on the city's more apparent manifestations. "The city itself remains magical; it is a mysterious, chaotic and irrational place which can be organised and controlled only by means of private ritual or public superstition" (London: The Biography, p. 207). Based on this persuasion, Ackroyd regards London from the perspective of such themes and phenomena as the city's murders and other violent crimes, smells, voraciousness, occultism and mysticism, and its various outcasts, be it the poor, the insane or the visionary. As a result, certain discourses which are not grounded in rational reasoning become an inseparable part of his London's texture, due to which his wandering "will sometimes stray from the narrow path in search of those heights and depths of urban experience that know no history and are rarely susceptible to rational analysis" (London: The Biography, p. 2). By this focus on the dark sides of London Ackroyd attempts to lay bare its latent, unconscious levels and processes, thus "developing a kind of gothic psychogeography that explores [...] the more extreme forms of behavioral response provoked by the city" (Coverley, 2006, pp. 124-125). It is precisely the extremity of the obscure and the uncanny that he believes continually affects and underlines the city's orderly and decent mundane experience.

Having claimed composing an exhaustive, continuous history of the city impossible, Ackroyd's biography of London is deliberately prone to fragmentation - it is organised around various themes and phenomena typical of the city and its life rather than following a chronological order. The sequencing of historical events is reduced to a mere overall framework within which the book's inner structure can become loosened, diversified, and sometimes even inconsistent, yet always interconnected through repetitive cyclical and spiral temporal patterns, as a result of which the past incessantly resonates in the present: "The biography of London also defies chronology. [...] That is why this book moves quixotically through time, itself forming a labyrinth" (London: The Biography, p. 2). Ackroyd calls this concept "chronological resonance" ("The Englishness of English Literature", p. 339), seeing this labyrinthine city as one in which the present always echoes and re-experiences the past, which shapes and prescribes not only the inhabitants' behaviour, but also their very characters and identities. His method thus combines a psychogeographic approach with a kind of historic-mystical antiquarianism whose "sense of endlessly recycled past negates any attempt by individuals to change the fundamental nature of their environment" as their "actions and beliefs [...] are seemingly of little or no consequence" (Coverley, 2006, p. 127). Ackroyd is concerned with the personality or character of the city which involves and by far surpasses that of its dwellers: "To read Ackroyd is to become aware that while the physical and political structure of London may have mutated down the ages, as torrents of men and women coursed through its streets, yet their individuality is as nothing, set beside the city's own enduring personification" (Self, 2007, p. 11). Though in both London: The Biography and his London novels Ackroyd elaborates on the idea of the city as a total sum of its inhabitants' experiences and energy and focuses on an individual's perception of the urban milieu, it is London that remains his main hero, an all-encompassing space-time continuum and all-pervading defining principle, one which transcends and crucially determines the fates of all those it has ever involved. It is an infinite city which "goes beyond any boundary or convention" and "contains every wish or word ever spoken, every action or gesture ever made" (London: The Biography, p. 760). Ackroyd's psychogeographic antiquarianism consists in collecting all the possible texts and narratives, both official and private or popular, that he assumes have come into existence as a result of London's impact on its inhabitants' mind, and which therefore reflect its spirit, and subsequently exploiting them — rewriting, recycling and juxtaposing them, drawing speculative connections between them-in order to compose a biographical history of his beloved city. 


\section{The Dungeon of Man's Desires, a Labyrinth of Stone and a Motley Parade-Ackroyd's London Walkers}

The two distinctive walkers of London streets in Hawksmoor, Nicholas Dyer and Nicholas Hawksmoor, make an interesting twosome of characters: the first is a famous architect but also a heartless serial killer, the latter a detective investigating a series of petrifying murders that have been committed in the sites of Dyer's churches; yet, what separates them is not only the side of the law they stand on, but, more importantly, some two hundred and seventy years of historical time, between the early eighteenth century when the churches were built and the late twentieth century work of the criminologist. In terms of their personalities, however, the two men have much in common as they both are rationally-thinking individuals relying on reason and logic, but, at the same time, they strongly believe in their intuition, or some kind of a sixth sense, and, as a result, they admit that the world is impossible to comprehend fully merely by rational cognitive processes. The list of their similarities would be long, including not only identical features in their appearance and behaviour, but also in their feelings, such as "they both feel a strong wish at certain point to dress and behave like tramps [...], and they are darkly aware that they are undergoing a process of self-fragmentation and alienation from society" (Onega, 1999, p. 46). Therefore, they both are more sensitive to various irrational, or rationally inexplicable, manifestations around them, possessing the capacity to recognise and realise diverse impacts of the city on human psyche. Moreover, for the sake of their job, they need to be particularly well-acquainted with London's topography, and these two factors make them exceptionally alert observers of the city and its less obvious and covert mechanisms and phenomena.

Young Dyer spends much of his free time reading captivating stories, mostly of scholars dealing with magic or supernatural forces, such as Marlowe's Doctor Faustus or Greene's Friar Bacon and Friar Bungay, but he shows little enthusiasm for reading the texts presented to him at school. However, the curious boy loves to explore and experience the world around, and so, whenever he can, he rambles the streets tirelessly, carefully taking note of every single detail, from people to buildings, his imagination picturing the city of the past as well as projecting that of the future. For him, London is like an immense textbook to be studied and inspired by, much more interesting and effective than a school education. Therefore he often plays truant in order to absorb and understand the city's spirit, "walking abroad into that great monstrous Pile of London: and as I felt the City under my Feet I had a habit of rowling Phrases around my Head, such as Prophesie Now, Devowring Fire, Violent Hands, which I would then inscribe in my Alphabeticall Pocket-Book along with any other odd Fancies of my own" (Hawksmoor, p. 13). However, as he grows up and changes from an eager learner and Sir Christopher Wren's gifted pupil, into a misanthropic, secret Satanist, his perception of the city develops into that of a devilish creation of chaos and confusion, "the Capitol of Darknesse", "the Dungeon of Man's Desires", "the smokey grove of Moloch" (Hawksmoor, pp. 47-48). Dyer sees the bulging, unrestrained and uncontrollable London as an incarnation of the devil, an aggregate of all thinkable forms of human incompetence, evil and misery, one which only breeds further pain and despair. As he tries to reveal such an image of the city to Nat, his assistant:

Thus London grows more Monstrous, Straggling and out of all Shape: in this Hive of Noise and Ignorance, Nat, we are tyed to the World as to a sensible Carcasse and as we cross the stinking Body we call out What News? or What's a clock?. And thus do I pass my Days a stranger to mankind. I'll not be a Stander-by, but you will not see me pass among them in the World. [...] What is their God but shineing Dirt to sing its Devotions come the Westminster-Hall-whores, The Charing-cross whores, the Whitehall whores, the Channel-row whores, the Strand whores, the Fleet Street whores, the Temple-bar whores [...] and my Voice grew faint through the Curtain of my Pain. (Hawksmoor, p. 48)

The city which so much inspired youthful Dyer, whose passion for its topography and the particular designs of its streets and alleys made him at first a zealous student and later a respected architect, like his mind, gradually transforms into a place of doom and insanity; instead of offering learning and other professional challenges it fills him with the blinding desire to complete his great, magic designs, which are to bring him salvation, no matter how many killings and other forms of suffering they will require. A crucial role in Dyer's vision of the urban inferno is played by his deluded persuasion that he himself is excluded from this material being, rectifying not participating in the vicious circle of evil. As a "chosen" one, he understands his life as a kind of otherworldly presence in the earthbound reality, a prophetic and messianic mission whose aim is to open other people's eyes by showing them and making them worship and serve the proper deity. Yet, when others, for whatever reasons, fail to awaken and look through the haze of their misconception and folly, he resolves to save himself through locating his churches as seven vertexes in a mystical, occult pattern, combined with human sacrifices buried in their foundations to please his Saviour. As the living prove deaf to his appeals and revelations he eventually turns to the dead which can be seen in the different nature of his later walks along London cemeteries, yet one question troubles him still: "why do the Living still haunt me when I am among the Dead?" (Hawksmoor, pp. 88-89). The cityscape of his strolls reflects the state of his mind and vice versa. He no longer walks in the city centre, along the peopled streets and 
markets, but prefers places of isolation and solitude, churches and graveyards, as it is only there that he finds souls who share with him his experience of the cursed city's oppressive might. It is also where he hopes he can reach communion with what he considers the true voice of London, and, in consequence, also the vox mundi, a supratemporal echo of the wisdom of the dead which the doubting and blasphemous words of the living only shout down and stifle. It is the world of the dead he roams, it is the world of the dead his disturbed psyche starts to resemble, and it is the world of the dead he pays homage to and wishes to cross over to by his every act.

The CID detective Nicholas Hawksmoor badly needs to find the prime suspect of the long-investigated serial killings, a mysterious vagrant nicknamed the Architect. Therefore, as he believes that every perpetrator eventually returns to the scene of his or her crime, the chief purpose of his pensive walks in the vicinities of Dyer's churches is to stay close to the areas where the murderer has committed his acts, and, assuming that he will recognise him when he sees him, to hope that he will encounter or spot him there. During one of these walks, though, because he had previously broken his glasses, and perhaps because of this, he catches sight of a suspiciously looking tall vagrant on the other side of the street, but while in pursuit, the vagrant gets nervous and starts running away, soon vanishing from the detective's sight "in the abandoned sites and derelict houses near St Anne's" (Hawksmoor, p. 197). All Hawksmoor finds eventually is a harmless group of other vagrants who show no willingness to cooperate and so he at least wreaks his anger on them by forcing them to put out their fire. The city of his mind thus becomes like that of the homeless tramps, meths-drinkers and waste-collectors-a dreary, inconsolable landscape of desolation and solitude, whose worries and pleasures do not reach beyond the present moment.

The desperate Hawksmoor carries on with his walks at first in order to devise a strategy which would help him catch the Architect, and later to clear his mind of the various preposterous and semi-delirious thoughts and fantasies. Although his consciousness strives to figure out a new, yet untried way of solving the case, his unconscious instincts are powerfully at work too and drive him relentlessly to what his rational self deems futile or foolish. Therefore, no matter how aimless and randomly directed these ramblings are, he always ends up in the same areas where he has been tracing his suspect already.

He took long walks in the evening in order to avoid such thoughts, but he found that he was treading the same paths as before. There was a time, for example, when he walked into the park behind St George's-in-the-East and sat upon a bench closed to the abandoned museum - it had been upon this bench that he had spoken to the father of the murdered child [...] And as he stared at the trees beside the church he contemplated the calm of a life which itself resembled a park with no people in it-then he might sit and stare at these trees until he died. But his momentary serenity unnerved him, for it seemed to imply that his life was already over. (Hawksmoor, p. 198)

Hawksmoor is too much captivated by his pursuit and the topography of the terrain where it is being carried out, reminders of his professional and personal inadequacy and failure, to find solace and composure in an escapist, pastoral image of a still city life of a foreseeable future. The transient and illusory tranquillity of the park behind one of the crime scenes does not give the experienced detective a sudden lucidity of the city and the criminal case, on the contrary, it only confirms for him that he has got stuck in a blind alley where there is "in any case no future and no past, only the unspeakable misery of his own self" (Hawksmoor, p. 199). His restless mind is thus doomed to wander the urban wasteland until it reaches peace through a mysterious, transtemporal connection with the mind of the killer, "his black emanation" (Onega, 1998, p. 47), inside the non-existent church of Little St Hugh, in what may be interpreted as both a mystical act of "a transcendent communion across the centuries" (Lewis, 2007, p. 44) within London's collective experience, as well as another hallucinatory stage of Hawksmoor's progressing insanity.

Elizabeth Cree and George Gissing are two compulsive London walkers in Dan Leno and the Limehouse Golem, yet the motivation for their journeys is far from getting to know the city's back streets or feeling its unique atmosphere and spirit. Although they are in many respects different personalities, what drives them into the streets is strikingly similar: the dismal and depressing situation in their destitute homes. Other common features of their walks, though also determined by different circumstances, are that they mostly take place in the evening or at night and that they, in an unforeseen manner, crucially affect the walkers' future fates. Elizabeth keeps leaving her place of living in order to escape the psychically as well as physically harmful effects of her heartless, rigid, quarrelsome and religiously bigoted mother's upbringing and household keeping. Yet her at first directionless ramblings soon find a purpose in the form of the prospective fulfilment of her childhood wish to see a popular variety show, an act denied to her by her mother's persuasion that all places of entertainment are accursed, sinful abodes of the devil's making. Once she sets out for the nearest music-hall, her mood is suddenly completely unalike that of when she is bringing sewed sailing cloths to the docks or accompanying her mother to the local chapel—cheerful, fearless and resolute, despite the dangers the vast night city renders for a lonely young woman. When she eventually reaches 
the saloon of varieties, its bright and colourful façade creates such a contrast to the plain-looking and run-down vicinity that it stirs in her excitement as if she had found a diamond in a pile of dirt. Fascinated and attracted by the saloon she roams the neighbouring streets and alleys, lingering "among the congeries of byways and alleys that lead into the Strand" (Dan Leno and the Limehouse Golem, p. 17), mustering the courage to enter it. It is here when the area's topography gets reflected in Elizabeth's mind: the shabby back streets full of drunkards, pimps and prostitutes remind her of her hard and miserable existence, the old churchyard of her mother's semi-delirious, malevolent bigotry, and so the music-hall naturally becomes a place of both ease and thrill, an oasis of hope for a better and happier life set free from the restraints of narrow-mindedness and poverty. Later on, when she has to end her career as a music-hall performer, however, the same topography transforms into a mental background as well as a physical terrain for the realisation of her vengeful homicidal schemes, through which her disturbed psyche seeks to vent her accumulated frustration, yet which can be also understood "as particularly violent traces of the city's disturbing identity" (Gibson \& Wolfreys, 2000, p. 205). Her transformation into the Limehouse Golem thus symbolises "the emanation of London's spiritual sickness" (Onega, 1998, p. 68). These nocturnal walks are no longer aimless, desperate acts of a runaway victim of hardships, but those of a focused, cold-blooded predator in search of prey for her deranged fantasies.

The motif of the cityscape as a projection of a murderer's and a writer's mind is introduced in Dan Leno and the Limehouse Golem through De Quincey's famous essay "On Murder Considered as One of the Fine Arts" (1827), in which John Williams, the Ratcliffe Highway murderer, is presented as a particular amalgam of a romantic hero, "an outcast who enjoys a secret power" (Dan Leno, p. 37), and an original artist of a sort, "an urban Wordsworth, a poet of sublime impulse who rearranges (one might say executes) the natural world in order to reflect his own preoccupations" (Dan Leno, p. 37). Williams thus features as a walking spirit, or "an avenging angel", of London which "becomes a brooding presence behind, or perhaps even within, the murders themselves" (Dan Leno, p. 38). Such an image of London, Ackroyd suggests, is rooted in De Quincey's early experience with life in the city, when the area around Oxford Street became for him one of sorrow, poverty and loneliness, and his misery and frustration also stood behind his first purchase of laudanum. Therefore, this city of suffering and despair, "a labyrinth of stone, a wilderness of blank walls and doors" (Dan Leno, p. 39), even in his later writing, represented "the landscape of his imagination" (Dan Leno, p. 39), the city of his mind. De Quincey's "On Murder" then becomes a brooding presence behind the novel's plot as it influences, inspires or captivates several of its key protagonists, namely George Gissing, John Cree, Elizabeth Cree and Karl Marx. Most of them attend the Reading Room of the British Museum where they are reading De Quincey and other London texts, and produce or dream of producing a London text of their own. It is the Reading Room, a site which Ackroyd considers the spiritual centre of London, where the interconnection between the actual city, its literary representation and the city of one's imagination and consciousness can most naturally materialise itself. And so "the murmuring of all the inhabitants of the Reading Room rose towards the vast dome and set up a whispering echo like that of the voices in the fog of London" (Dan Leno, p. 47), same as the read texts echo the interaction between their authors' creative processes and the city's mental and physical topography.

The reason behind Gissing's night expeditions through London streets is even more peculiar than that of Elizabeth Cree as he is actually often looking for his own wife, known since her orphaned childhood as Nell, and who has recently resumed drinking and prostitution, hoping in vain that he would persuade her of the benefits and joys of decent family life. The desperate young writer thus spends his nights chasing Nell around various parts of the East End, and visiting all the existing brothels in the vicinity where she possibly could be engaging in her profession. However, saving Nell from the snare of vice and himself from public shame is not the only purpose of his walks, not even the principal one- - his walks around Limehouse and its neighbouring areas serve him as research for his article about Charles Babbage and his Analytical Engine. As Gissing does not understand the mathematical principle and technical mechanisms of the ingenious computing machine, he believes that he could approach Babbage's mental processes by thorough exploration of places he was fascinated with, like, for instance, the Limehouse church of St Anne's with the large white pyramid erected in its front ground. Feeling "a shrinking uneasiness" (Dan Leno, p. 120) in the presence of the mysterious apparatus, Gissing insists on its connection with the spirit of the unfortunate area in which it was constructed, especially with "the white pyramid in the grounds of the church of St Anne's which so impressed Charles Babbage himself” (Dan Leno, p. 121). And so, in a truly psychogeographic manner, Gissing arrives at scrutinising the interference between his own wounded psyche, rather than the mind behind the invention, and the topography of the place he so much associates with his misery and degradation. His writing of an essay on the Analytical Engine thus becomes an autotherapeutic means of his coming to terms with his failures by putting at least a part of the blame on the city which allowed them to happen to him. "Gissing is thus used by Ackroyd as a medium for the city, for its traces and its textual reconfigurations" (Gibson \& Wolfreys, 2000, p. 208). Ironically, nothing of this seems to have been spotted by his renowned leftist 
admirer, Karl Marx, who reads it solely for the technical details, thinking of the Engine's potential use for the benefits of a communist society.

Ackroyd's Gissing is a character exceptionally sensitive about the genius loci of London and its impact on the citizens' lives and psyches, and as such he develops a highly ambiguous attitude to the city, one perpetually alternating between fascination and delight on the one hand, and indignation and repulsion on the other. He experiences the first on his way to the Reading Room and it is the area around the British Museum, "the locus for so many ethereal words and thoughts" (Lewis, 2007, p. 87), where he feels to be himself and happy again, as

It was the spirit of the district itself which, he supposed, affected him so profoundly. Even the tradesmen he passed on his walk to the museum [...] seemed to share his sense of place and to accommodate themselves to it. He knew the porters and the cab men, the strolling musicians and the casual street-sellers, and he considered them as part of some distinctive human family to which he also belonged. (Dan Leno, p. 138)

His is therefore a most telling example in the novel of how the atmosphere and spiritual connotations of a particular locality may affect a person who comes to inhabit or even only repeatedly move around it. The intellectual and creative climate of the Reading Room, with its accumulated wisdom, knowledge and experience, Gissing believes, spreads far beyond the walls of the building, making more thoughtful and self-reflective individuals feel elated and optimistic concerning their future accomplishments in its vicinity. However, when he once decides to set off in another direction, eastward towards the Strand, and finds himself in an unfamiliar maze of streets around Clare Market, his former dejection because of the dark side of the city returns as he walks around streets full of rubbish and excrement, past a dimly lit rag shop with naked and half-starved little children sitting on the filthy mud floor, and a manufactory smelling unbearably of lead and acid, in which several lines of hard-working women sing in unison in the overpowering din and billowing smoke. It is while he is hastily leaving this hellish place that he comes to understand that London consists precisely of such contradictory, seemingly incongruent elements, whose incessant clashes and encounters constitute the very fabric of the material and mental cityscape: "perhaps there was such a place where perpetual, infinite, London would one day be found. But perhaps he had found it already - perhaps it was in him, and in each of the people he had encountered that night" (Dan Leno, p. 246). At this moment the young writer experiences some sort of urban epiphany, an Ackroydian Cockney visionary revelation about the eternal, mystical London which comprises, stores, and therefore also transcends, every moment and act lived within its limits. It is as if he could find peace within the teeming, and at times intrusive, city when he understands and accepts his subordinate position within this mass of collective experience and wisdom. It also suggests that he can only approach the city meaningfully, and thus be reconciled with it and reach contentment even on a personal level, when he sets his mind free of any illusions, self-projections and preconceptions and lets this universal city reflect itself in his mind, and, in consequence, lets the city and his mind become one. Only such a passive yet receptive state enables him to raise himself above the mundane, tedious worries and affairs of everyday life.

In The Lambs of London, Charles Lamb is the most faithful and sensitive observer of the city. Despite his insecurities, worries of inadequacy and fears of professional failure, he manages to retain an optimistic and enthusiastic attitude to London, which he sees as both a place of countless opportunities as well as an inexhaustible source of artistic inspiration. "Ackroyd draws upon Lamb's essays, especially the miscellaneous pieces written in the persona of Elia, to round out the portrait of this true Londoner" (Lewis, 2007, p. 138). Therefore, although often volatile and doubtful concerning his writing, Charles is very firm in his views of the city which he especially enjoys during his flâneries, walking slowly, watching carefully and with zeal all the details of diverse city life:

He joined the throng of carriages and pedestrians, all moving eastward into the City. It was for him a motley parade, part funeral procession and part pantomime, evincing to him the fullness and variety of life in all its aspects $[\ldots]$ The sounds of footsteps on the cobbles mingled with the rumble of the carriage wheels and the echo of horse hooves to make what Charles considered to be a uniquely city sound. It was the music of movement itself. (The Lambs of London, pp. 27-28)

Charles's London is thus a distinctive crossbreed of a physical and mental space, a cheerful cityscape containing projections of all his hopes, dreams and aspirations. Moreover, such a milieu always offers a multisensual experience, from the heterogeneous spectacles of the crowded streets to the euphonic sounds echoing the momentum of the city in full swing.

The title of the novel invites two contrary interpretations: on the one hand, there is the timid and neurotic Mary Lamb and William Ireland, whose fate as a gifted yet neglected boy too eager to prove his worth to his dismissive father using his imagination and artistic inclinations initially appears as if taken from a prototypical English 
Bildungsroman, who become the true victims, or sacrificial lambs, of the city (Note 1); Charles, on the other hand, despite, or maybe because of, his carelessness and levity, survives in the city and becomes the Lamb of London through his career as a popular writer. Although he loves the city enormously, he is simultaneously aware of its destructive potential: "He was part of the crowd. There were times when this brought him comfort, when he considered himself to be part of the texture of life. There were occasions when it merely reinforced his sense of failure. More often than not, however, it spurred his ambition" (The Lambs, p. 28). Feeling himself part of the mass of the city's collective experience, his mind associating the city with the promises of a bright future, Charles never ceases to believe in its potential to endow its dwellers with the freedom necessary for ever achieving their most secret goals. For Charles, the city, more than anything else, represents life in all its miscellaneous forms and, consequently, a challenge to meet. He may be light-hearted and youthfully irresponsible, at times prone to brief gloomy periods of self-doubt, but he always seems to possess the optimistic spirit and vigour essential for grasping the opportunities London offers to those who are bold and ready enough to take advantage of them. "I am always lucky in the London streets, Mary. I lead a charmed life in the city" (The Lambs, p. 47), he replies when his sister makes a grim point that he could consider himself fortunate when he is robbed on one of his night-time returns from the pub but left uninjured, as if suggesting that the city would always spare those who resonate with its spirit. Once again, Ackroyd's London becomes a metaphor and the cornerstone of one's ability to keep one's head up even when things do not look particularly auspicious, as it is the only successful strategy of how to face up the demands of, and survive in, the rapidity of the modern urban world.

William Ireland is a much differently motivated stroller. Unlike Charles Lamb, who takes delight in the spectacles of bustling life and thus seeks the crowded parts of the central city in daytime, Ireland sets out into the London streets with the sole purpose of being alone, having time to mediate on the technicalities of his forgeries and their presentation to the outside world, for which he needs to remain hidden and unrecognised in the anonymity of the urban maze. Therefore, most of his walks are off the peopled thoroughfares, in the side streets and poor areas whose inhabitants have no idea what the Shakespeare Papers are or who their supposed discoverer is. Moreover, his solitary, ruminative ramblings often take place at night, the only time when he feels unthreatened by the unwanted attention of inquisitive and doubting intruders. William's attitude to the city is necessarily ambiguous: on the one hand, he needs it for his aims as only there can he gain recognition and perhaps even fame, yet, on the other hand, it simultaneously denies him what he needs most for a successful and smooth completion of his plans - peace and quiet for work, and as such it can easily ruin his life. For William Ireland, London is reduced to a few places he is familiar with, which he likes because he feels secure in them, like his room, his father's bookshop, or the library, but is in fact at odds with it as a whole. The city of his walks is a mental image, a detached fantasy rather than a real, physical space since he takes little notion of his surroundings, being enclosed deep in his thoughts and aspirations. Rather than an avid spectator of the countless urban dramas he is a director using the city as a stage for his carefully designed, private performances, an alternative, an essentially unnatural, reality which, therefore, proves hard to sustain as the city will resist a long-term imposition of such an illusion and unveil its true state of affairs. The protagonist's inability to come to terms with the particularities and regularities of city life, Ackroyd seems to suggest, brings about his inevitable downfall.

The Casebook of Victor Frankenstein is far from a merely modernised version of Mary Shelley's original since it challenges Frankenstein's role within the narrative, and, in consequence, his status as a narrator and the very viability of the story told. Combining a first-person narration of a self-deluded, and half-insane, serial killer with the discourse of mysticism, spiritualism, mystery and a hunt for the inexplicable, the novel primarily consists of elements of two historically distinct genres: the urban Gothic and the psycho-thriller. Naturally, the Gothic represents an ideal vent for the clash between the rational and irrational and, as some contemporary writers demonstrate (Note 2), can effectively capture the postmodern sensibility "because it questions the notion that one inhabits a coherent or otherwise abstractly rational world" (Smith, 2007, p. 11), and the fundamental horror of postmodern Gothic rests in that "the loss of belief in metanarratives marks out a final limit and then substitutes a plunge into limitlessness, an ultimate meaning as meaninglessness" (Botting, 2002, p. 296). The Casebook of Victor Frankenstein represents yet a different attempt at exploiting the genre since it offers an imaginative rendering of a Gothic myth that combines a highly subjective confession with historiographic and psychogeographic perspectives.

The city as a metaphor for the main protagonist's sick mind occurs very early in the novel, after Frankenstein attends the "galvanising" lecture of Humphry Davy. Having left the lecture room, he, for the first time, feels burdened by another self, a shadow that follows him through the streets of London and experiences a strong urge "to escape the confines of the city" (The Casebook of Victor Frankenstein, p. 31). However, the phantasm pursues him beyond the edge of the city where it even "saves" him from falling down when Frankenstein stumbles upon a 
root. When Frankenstein eventually regains consciousness after a nervous breakdown, his personality is altered and he believes to "have been marked out in a way that [he] could not then comprehend (The Casebook, p. 32). He is not only fully aware of his disorder but takes it as a sign of his exclusivity, seeing himself as a person chosen for some higher mission. When he turns back to London, its frightening image is gone, its noise reminding him of "a confused but not inharmonious muttering [...] an inchoate roar of vast life momentary stilled" (The Casebook, p. 33), and Frankenstein peacefully walks back towards the city. That the "inchoate roar" of the city parallels his inchoate madness appears to be plain enough. Throughout the novel, the city is recurrently employed as a reflection of his states of mind: he appreciates the soothing "immensity of London coming to life" (The Casebook, p. 156) after he has learnt the terrifying intensity of the electric fluid; he experiences the redeeming solitude of night walks in the otherwise "teeming city" (The Casebook, p. 165) while carrying out his experiments; when he is returning from a journey to the country, he can smell London as if he could smell the monster (The Casebook, p. 200); he walks absent-mindedly through the city during his hallucinations; and in the end, he walks through the streets accompanied by his "creation", together casting a shadow that is "bent forward, hastening onwards as if it had an existence of its own" (The Casebook, p. 383), showing that his acts are far beyond his conscious control. What makes Ackroyd's version of Frankenstein original, apart from the conceit of the protagonist's double personality, is the employment of the unreliable "mad monologist" narrator (Note 3) complemented by the lively explorations of London's underbelly and irrationalities. For the possessed Frankenstein, the cityscape and its spirit become identical with those of his wounded psyche. Ackroyd's Gothic London is a display of the various irrational aspects of the city but, above all, a terrain of insanity, a reflection of the main protagonist's deranged mind.

\section{Ineffable Solid Ground-Conclusion}

Ackroyd recognises two defining aspects of the London genius and its creative sensibility: the first is heterogeneity - the richness and diversity of forms, styles, moods and means of expression, both past and present - whose seemingly paradoxical or incongruent combination corresponds with the very nature of the city "where the extremes of the human condition meet, where one emotion or mood is quickly succeeded by another, where comedy and tragedy are to be seen side by side" ("London Luminaries and Cockney Visionaries", p. 348); the second is the continuous recurrence of certain tendencies, ideas, phenomena, actions and modes of expression across time, which he calls "patterns of continuity" ("The Englishness of English Literature", p. 331), and which crucially affect all spheres of the city dwellers' experience, most notably their imagination and attitude to the place they inhabit. Ackroyd's London novels then render and dramatise these two aspects, and the reflection of the city in their protagonists' minds is one of the most effective means of doing so. His Dyer, Hawksmoor, Cree, Gissing, Lamb, Ireland and Frankenstein, all in their own way and in the context of their time, attempt to come to terms and cope with the variety and unpredictability of London life, which involves inconsistent and often contradictory features and phenomena, such as prosperity and misery, success and failure, sanity and insanity, or recognition and obscurity. Yet although their stories differ, the principle remains invariant: in their mind, they struggle to find some balance between these extremes in order to give shape to their own identity and make sense of their existence in the city.

In all the discussed cases the individuals' reading and comprehending of the urban space coincides with the process of their getting to know themselves through the city, consciously or not, and, in consequence, with setting up their own position or role within it. Unlike his London: The Biography, Ackroyd's novels do not espouse a purely psychogeographic approach as their protagonists' urban wanderings are mostly not motivated by any purposeful and systematic tracing of the territories' vanishing properties, nor by any politically subversive stance (Note 4). Rather than actively pursuing London's hidden meanings it is actually the city that "takes them to task" by laying bare those concealed sides of their mind they have been unaware of, and impels them to seek to find harmony and concord between their unstable psyche and the multiple rhythms, currents and disturbances of the city. In his London novels, more than a psychogeographer Ackroyd is a psychogeographic antiquarian collecting, storing up, recording and reenacting as much of the accumulated past and present experience of and in the city as he can, both textual and lived, and exploring the diverse impacts it has had on the individual as well as the collective psyche of his Londoners.

Ackroyd's London walkers move around a place and space which transcend the limits of their rational understanding, whose immense physical as well as spiritual power and energy captures, if not overwhelms, its inhabitants' minds and therefore irreversibly affects their mental states and processes. All their acts of psychosomatic consummation of the streets, be they psychogeographic ramblings, antiquarian explorations, topographic naming and mapping, autotherapeutic soothing saunters, liberating escapes from the restraints of prejudice and convention, attempt at reconstructing one's identity through self-scrutiny and self-discovery, desperate struggles for fulfilling one's dreams and hopes, or unfolding of a disturbed psyche, reveal the very 
ambiguous nature of this cityscape, oscillating between familiarity and unfamiliarity, comprehensibility and incomprehensibility, intimacy and estrangement, immediateness and alienation. "What Peter Ackroyd strives to make us familiar with is that London remains ineffable. It resists definition, by being nothing more than the voices, the texts, the traces of itself, endlessly reconfigured and performed, time and time again" (Gibson \& Wolfreys, 2000, p. 210). Yet no matter how infinite and ultimately unknowable such a city is, Ackroyd seems to suggest that to resign from ever trying to approach it, and possibly partly make sense of it, means to defy its natural course. Towards the end of London: The Biography, he notes that London is not merely a state of mind, this being only one of its many roles and manifestations, as it contains "a world or worlds within itself" (London: The Biography, p. 750). However, it does represent a crucial aspect as people have always been, and always will be, attracted by the city's "sensation of permanence, of solid ground" (London: The Biography, p. 750) to identify themselves with its genius regardless of how hostile and destructive it can be.

\section{References}

Ackroyd, P. (1993). Hawksmoor. London: Penguin Books.

Ackroyd, P. (1994). Dan Leno and the Limehouse Golem. London: Vintage.

Ackroyd, P. (2002). London Luminaries and Cockney Visionaries. In T. Wright (Ed.), Peter Ackroyd: The Collection: Journalism, Reviews, Essays, Short Stories, Lectures (pp. 341-351). London: Vintage.

Ackroyd, P. (2002). The Englishness of English Literature. In T. Wright (Ed.), Peter Ackroyd: The Collection: Journalism, Reviews, Essays, Short Stories, Lectures (pp. 328-340). London: Vintage.

Ackroyd, P. (2003). London: The Biography. New York: Anchor.

Ackroyd, P. (2005). The Lambs of London. London: Vintage.

Ackroyd, P. (2008). The Casebook of Victor Frankenstein. London: Vintage.

Atkins, M., \& Sinclair, I. (1999). Liquid City. London: Reaktion Books.

Bentley, N. (2005). British Fiction of the 1990s. London: Routledge.

Botting, F. (2002). Aftergothic: Consumption, Machines, and Black Holes. In J. Hogle (Ed.), The Cambridge Companion to Gothic Fiction (pp. 277-300). Cambridge: Cambridge University Press. http://dx.doi.org/10.1017/CCOL0521791243.014

Bubíková, Š. (2001). The Literary Image of Man in the Process of Becoming: Variations of the Bildungsroman Genre in English and American Literature. In American and British Studies Annual (Vol. 4, pp. 116-130). Pardubice: University of Pardubice.

Coverley, M. (2006). Psychogeography. Harpenden: Pocket Essentials.

Debord, G. (1981). Introduction to a Critique of Urban Geography. In K. Knabb (Ed.), Situationist International Anthology (pp. 8-11). Berkeley CA: Bureau of Public Secrets.

Gibson, J., \& Wolfreys, J. (2000). Peter Ackroyd: The Ludic and Labyrinthine Text. Basingstoke and London: Macmillan Press Ltd. http://dx.doi.org/10.1057/9780230288348

Hayes, M. H. (2007). Understanding Will Self. Columbia: University of South Carolina Press.

Lewis, B. (2007). My Words Echo Thus: Possessing the Past in Peter Ackroyd. Columbia: University of South Carolina Press.

Lively, P. (1992). City of the Mind. London: Penguin Books.

Mengham, R. (2003). The Writing of Iain Sinclair. In R. J. Lane, R. Mengham, \& P. Tew (Eds.), Contemporary British Fiction (pp. 56-67). Cambridge: Polity Press.

Murray, A. (2007). Recalling London: Literature and History in the work of Peter Ackroyd and Iain Sinclair. London: Continuum.

Onega, S. (1998). Peter Ackroyd. Plymouth: Northcote House.

Onega, S. (1999). Metafiction and Myth in the novels of Peter Ackroyd. Columbia: Camden House.

Self, W. (2007). Psychogeography. London: Bloomsbury Publishing.

Sinclair, I. (2003). Lights Out for the Territory. London: Penguin Books.

Smith, A. (2007). Gothic Literature. Edinburgh: Edinburgh University Press.

Tew, P. (2004). The Contemporary British Novel. London: Continuum. 
Weiss, R. (2010). “Hell is a city much like London”: Postmodern Urban Gothic in Charles Higson's Getting Rid of Mister Kitchen. In P. Chalupský, \& A. Grmelová (Eds.), Litteraria Pragensia (Vol. 20, No. 40, pp. 54-69). Prague: Charles University.

\section{Notes}

Note 1. For a more detailed discussion of the English version of the Buildungsroman genre see Bubíková, pp. 120-124.

Note 2. These are namely Patrick McGrath, Charles Higson and Diane Setterfield All of McGrath's novels follow the Gothic mode of narration, elements of Gothic or neo-Gothic fiction can also be found in Higson's Getting Rid of Mister Kitchen (1996) and Setterfield's The Thirteenth Tale (2006).

Note 3. A more thorough exploration of this narrative device can be found in Rudolf Weiss's "Hell is a city much like London": Postmodern Urban Gothic in Charles Higson's Getting Rid of Mister Kitchen, pp. 56-58.

Note 4. Save for the politics of representation and narrative logic as Murray argues, pp. 39-40.

\section{Copyrights}

Copyright for this article is retained by the author(s), with first publication rights granted to the journal.

This is an open-access article distributed under the terms and conditions of the Creative Commons Attribution license (http://creativecommons.org/licenses/by/3.0/). 